\title{
Essais
}

Revue interdisciplinaire d'Humanités

$2 \mid 2012$

Aux marges de l'humain

\section{Vivre entre les grammaires}

Conversation avec Judith Butler

Brice Chamouleau, Bertrand Guest, Sandra Lemeilleur et Jeffrey Swartwood

\section{CpenEdition}

Journals

Édition électronique

URL : https://journals.openedition.org/essais/10527

DOI : $10.4000 /$ essais. 10527

ISSN : 2276-0970

Éditeur

École doctorale Montaigne Humanités

Édition imprimée

Date de publication : 15 novembre 2012

Pagination : 105-111

ISBN : 978-2-86781-857-8

ISSN : $2417-4211$

\section{Référence électronique}

Brice Chamouleau, Bertrand Guest, Sandra Lemeilleur et Jeffrey Swartwood, «Vivre entre les

grammaires », Essais [En ligne], 2 | 2012, mis en ligne le 17 janvier 2022, consulté le 20 janvier 2022

URL : http://journals.openedition.org/essais/10527 ; DOI : https://doi.org/10.4000/essais.10527 
Conversation menée, transcrite et présentée par Brice Chamouleau, Bertrand Guest, Sandra Lemeilleur et Jeffrey Swartwood.

Brice Chamouleau, université Michel de Montaigne Bordeaux 3, EA 3656 Ameriber

Bertrand Guest, université Michel de Montaigne Bordeaux 3, EA 4195 Telem

Sandra Lemeilleur, université Michel de Montaigne Bordeaux 3, EA 4426 Mica

Jeffrey Swartwood, université Michel de Montaigne Bordeaux 3, EA 4196 Climas

N.D.L.R.

Entretien réalisé à l'université Michel-de-Montaigne

Bordeaux 3 le 5 octobre 2011. 


\section{Vivre entre les grammaires}

\section{Conversation avec Judith Butler}

En ne procédant pas à une réécriture qui en aurait alourdi et figé le flot, c'est volontairement que nous avons conservé à cette brève conversation ses caractéristiques orales: phrases minimales ou nominales, énumérations, répétitions et reformulations. Il nous a semblé plus intéressant de donner à voir les processus de pensée au moment où ils se forment, au moment dialogique du questionnement, que d'en figer un illusoire résultat, sans parler d'en tirer une théorie. Aussi avons-nous essayé, fidèles à cette critical inquiry que demeure la recherche, toujours en cours de route, de nous en tenir à la pensée en train de se formuler plutôt qu'à des productions déterminées une fois pour toutes.

Plus qu'un simple recours oral et situationnel ou une ruse pédagogique, le passage d'une langue à l'autre s'avère être en ce sens une véritable méthode philosophique. Déterminée à faire jouer l'apport de chaque langue à ce qui est en train d'être pensé, Judith Butler fait feu de tous les "bois de la langue ", comme l'aurait écrit Henri Meschonnic ${ }^{1}$, s'appuyant sur les modaux de l'anglais comme

1. Cf. Henri Meschonnic, Dans le bois de la langue, Éditions Laurence Teper, 2008. sur la rigueur classique de la construction française. Tel "gallicisme", tel " anglicisme", plutôt que des reliefs qu'une transcription scrupuleuse aurait dû gommer, ne sont-ils pas les formes d'un langage qui puisse mieux dire cette vie qui se déploie entre les grammaires, ce tâtonnement de la pensée, multilingue par nature?

Sous des apparences brutes et peu retravaillées - tout le texte relève du [sic] -, nous avons l'espoir de montrer un échange où se dit la souplesse d'une pensée en acte.

Sandra Lemeilleur (SL) : Je travaille sur une forme d'anthropologie du contemporain des sciences de l'information et de la communication et je m'intéresse à l'expressivité de l'intime dans les espaces du virtuel.

Brice Chamouleau (BC): Ma recherche porte sur l'historicisation des catégories du public et du privé dans l'Espagne post-franquiste, que j'envisage à la lumière de la question homosexuelle masculine.

Jeffrey Swartwood (JS): I work on representations and hybridity on US-Mexican border. 
Judith Butler (JB): Yes. Are you yourself American?

JS: Yes. I've been in France for twelve years. I'm really trying to look at a getting away from the bipolar Anglo-Hispanic construction that we tend to use; and to point out on how much more it's nuanced, especially to look at the history of representations in literature and cinema. How they revolved over the past sixty years. These are broad lines of what I'm doing.

JB: Yes. Great.

Bertrand Guest (BG) : Je travaille en littérature comparée sur l'écologie littéraire au XIX ${ }^{\mathrm{e}}$ siècle. Je me concentre sur la référence politique à la nature et l'écriture d'une géographie de la liberté dans les ouvres essayistes de Thoreau, Humboldt et Élisée Reclus. BC: Nous aurions aimé, puisque nous présentons nos champs disciplinaires, savoir comment est-ce que vous vous définissez, comment est-ce que vous vous situez...

JB : Moi? Judith Butler? Non. Je n'ai pas de définition.

BC: Vous êtes présentée pour ce colloque à la fois comme philosophe et titulaire d'une chaire de rhétorique et de littérature comparée.

JB: Formée en philosophie. Je travaille maintenant la littérature comparée, la théorie critique, l'étude du genre, les études interdisciplinaires, la théorie sociale, la théorie politique. Je ne sais pas. Ce n'est pas très important pour moi. Pas du tout.

SL: Dans le reportage de Paule Zajdermann, "Philosophe en tout genre", diffusé sur Arte en oc- tobre 2008, vous dites: "Avant d'être une femme ou une Juive ou une Américaine ou une citoyenne ou une philosophe, je voyage entre les identités ". Cela s'arrêtait comme ça. $\mathrm{JB}$ : Ce n'est pas la question. C'est une question que je pose. Ce n'est pas possible pour moi de rendre compte de moi-même ${ }^{2}$. I don't want to conform to categories of identity, right? I mean my whole work is very funny.

JS: Would you say you are encumbered by that? How people are projecting their categorization of you and of your work upon their reception of it.

JB: No. It does not belong to me. My work belongs to the people who read it, so I don't try to take it back, or own it, or say "No, you can't do that with my work", you know, or "I'm burdened by your appropriation." No! It does not belong to me. We live in a world in which it circulates, so it is a kind of counter narcissism, I'm scattered.

BC: Would you describe your practice as "queer" in the way that you deal with theories and disciplines, since you are straddling categories as defined within the university?

$\mathrm{JB}$ : I should say yes, I'm tempted to say yes, but then I worry that if I say yes, that would be an institutionalization of queer, comme identité. So, I want to resist, in the name of queer. In the name of queer I resist your question. But I don't resist it, I mean I'm glad: performance studies, for instance, it's

2. Formulation proche du titre exact de l'un des derniers livres de Judith Butler: Giving an Account of Oneself. A Critique of Ethical Violence, Fordham University Press, 2005. 
great to see what happens there: psychiatry, law, it is very interesting for me, but it does not belong to me. It is something new that comes back to me, that I have helped to make, but it comes back as a gift or a surprise. You know. But I don't go in and say: "no, that's not what I said." Maybe I did when I was younger [rires]. I don't do that anymore.

BG: I have a question linked to that, about interdisciplinarity. There has been an issue in France about "teaching gender"...

$\mathrm{JB}$ : I've been studying this.

BG: Cette question sur l'enseignement d'un savoir du genre ne poset-elle pas un système d'enseignement idéal? En objectant aux opposants de la théorie du genre qu'ils sont ignorants, on suppose un enseignement tellement transdisciplinaire qu'il est trop complexe pour la société d'aujourd'hui. Comment contourner dans l'enseignement cette difficulté de l'institution?

JB: First of all, it depends what we mean when we say that we teach gender. We are not teaching you how to be a gender. We are not telling you the absolute truth of gender. So, if we are not prescribing how to be a gender, and we are not giving you the new laws of gender, then: what does it mean to teach? It seems to me that there is a certain pedagogy which has to be opened up by the question of gender. What are the norms? How do they function? How to identify them? What is our relation to them? How have people represented them? What does it mean to have a critical re- flection on them? What are the common beliefs that need to be subject to a certain kind of critical inquiry, including biological determinism, Christian theology, sociobiology, functionalism? We have many... Why shouldn't we study them as we would study any set of cultural formations, in order to assess them, how do they ground themselves, how do they constitute themselves, what are the objections to them, how do we explain those objections in communicable language? I think that those who oppose the teaching of gender imagine that a dogma is being imposed, but actually it is a critical inquiry; it seems to me totally consonant with a minimum idea of the enlightenment. You don't even have to criticize the enlightenment to accept the legitimacy of gender studies in the academy: it can follow straight from that. But I'm not worried about gender being normalized within the academy. I think the more it is in the academy, the more it can be fought over, the more it becomes a site of debate, discussion, differing points of view, antagonism. We want it to be a field in which those kinds of conflict come to the fore.

BG: A field rather than a theory. So if queer were to be institutionalized, it would no longer be a critical inquiry? JB: No. If it is institutionalized, it should be institutionalized in such a way, that it can remain a critical inquiry! Il est nécessaire de développer une nouvelle pédagogie pour les études de genre.

SL: C'est l'idée qu'il faut qu'il y ait du débat entre les différentes disciplines. 
JB: Oui et au sein de chacune d'entre elles, par exemple en sociologie, en histoire, dans les études littéraires, en philosophie aussi. The study of gender has to be interdisciplinary. You will only be able to study some aspects of gender within any given discipline. But now it is such an intense site of legal debate - what gender are you? Can you change your gender? - psychiatric discourse - should it be diagnosed? How should it be diagnosed? Should it be not diagnosed? - historical formations - people who like Joan Scott, people who don't like Joan Scott... [rires]. I mean you can be a feminist and work on gender and not speak to one another; we saw some of that today ${ }^{3}$. Economics: the sexual division of labor. The gendering of poverty, the gendering of illiteracy: why are women more often than not the ones who are poor, and illiterate? If you are really going to study this, you will need to be able to be in interdisciplinary conversations to see all of its dimensions.

JS: So it's almost an ideal subject to introduce a methodology of analysis or questioning as an instructional technique, as a pedagogical tool...

$\mathrm{JB}$ : It produces all kinds of problems for methodology, that's true. I don't know if there is a single methodology. What it compels is a conversation between methodologies, and sometimes a disruption of methodology at its most basic level.

3. Judith Butler renvoie aux travaux du colloque "Sujets insoumis», organisé par Fabienne Brugère et Guillaume Le Blanc les 4 et 5 octobre 2011 à Bordeaux.
BC: Reading Foucault with Kafka, reading Claire Denis with Judith Butler...

SL: Je me suis posé une question sur la manière dont la stabilité de l'hétérosexualité était garantie dans les sociétés où l'homosexualité n'est plus prohibée par la loi.

JB : Les termes de la question m'intéressent: comment la stabilité de l'hétérosexualité est "garantie"? Garantie? Peut-être est-il important de distinguer entre critique de l'hétérosexualité obligatoire et critique de l'hégémonie de l'hétérosexualité, parce que nous vivons avec cette hégémonie, mais qu'elle n'est pas nécessairement obligatoire. Je ne veux pas me battre, I don't want to battle, contre l'hétérosexualité même. Ça existe. On peut dire qu' "il y a une "garantie" ", mais ce n'est pas la même chose que " la norme est obligatoire".

SL: L'idée est que dans la médiatisation des passages à tabac d'homosexuels, en France par exemple, objets d'une véritable monstration, il s'agirait de réutiliser ces faits pour signifier l'hégémonie de l'hétérosexualité. N'y a-t-il pas là un effet pervers de la médiatisation?

JB: Yes, but the very fact that that has been strongly put forward in the media shows that it is a struggle. It's not totalitarian. It has not achieved a totalitarian control, which is why they are fighting back. "We are now going to assert the hegemony of heterosexuality over and against these new sexualities that are gaining public legitimacy." It 
is a fight, so we have to treat it like a hegemonic struggle. Politically, I am not for the end of heterosexuality, I am not against heterosexuality, I don't want to see the dissolution of it, but heterosexuality is having anxiety about its inevitability. The regime of heterosexuality is suffering anxiety about its own inevitability.

SL: L'hétérosexualité sent vaciller sa permanence. Aujourd'hui cette lutte entre l'hégémonie de l'hétérosexualité et sa chute ne trouve-t-elle pas dans le « queer " un simulacre de l'abandon du genre qui reviendrait par effet inverse à la signifier à nouveau?

JB: Quelle est la supposition ici? Que le genre disparaît?

SL: Le genre est dépassé maintenant que le " queer» existe.

JB : Qui dit une chose pareille?

SL: Moi... à titre d'hypothèse. Dans les mangas japonais existent des personnages dont on n'arrive plus à savoir s'ils sont hommes ou femmes. Cette figure de l'androgyne est intéressante, où les traits ne se préoccupent plus de genre. N'y a-t-il pas là une volonté d'en finir jusqu'avec les signes du genre?

JB: Tu connais le travail de Shizuka Takamura? Elle a écrit sur le genre au Japon. C'est aussi une traductrice. C'est possible de penser le genre non comme substance, ni comme individu qui choisit le genre, mais comme opération des noms divers dans les médias, dans l'éducation, dans la loi. C'est aussi possible de le faire au Japon, c'est une autre grammaire: si je comprends bien, le verbe est central dans les propositions japonaises. Le verbe indique le genre. Le genre n'existe pas indépendamment du verbe.

SL: Tout est signifié dans le langage avant d'être dans l'image.

$\mathrm{JB}$ : Je voudrais suggérer aussi que nous faisons une erreur quand nous comprenons le genre comme substance ou comme sujet. Il y a des liens entre l'étude du genre performatif et l'étude du genre en chinois et en japonais. La comparaison entre expressions du genre m'intéresse beaucoup. Je pense que vous utilisez le terme de genre de façon très investie, là où je continue de le penser comme un simple problème théorique.

BG: Dans les poèmes amoureux des Han en Chine, l'homme et la femme sont indifféremment les destinataires. Ils portent un même vêtement.

$\mathrm{BC}$ : Est-ce que le genre est colonial? Est-ce que dans les usages qu'on fait, dans nos démocraties, de la notion de genre, cette notion peut être coloniale? Dans la dernière Gay Pride de Bordeaux, qui ressemble à beaucoup d'autres Gay Prides en France, il a par exemple été question de l'Iran. Est-ce que la déconstruction du genre peut s'exporter, et si elle s'exporte, n'est-elle pas coloniale? Cette question-là peut aussi se décliner à l'intérieur des frontières de la France, où l'on voit que l'accès à de nouvelles libertés pour l'individu n'est pas le même selon les espaces, ce qui entraîne l'utilisation des no- 


\section{RENCONTRES}

tions du genre pour discriminer des espaces comme les banlieues.

JB: You are speaking about a very specific discursive deployment of gender, within the space of maybe Paris or maybe France. But you have to know that this is a very culturally specific use. Now it may be that the culturally specific use to which you refer has a colonial function, but when I learn about gender studies programs in China or Japan, or in South Afri$c a$, or in Cairo, they are all anti-colonial projects. There is a very strong anti-colonial gender studies all over the world. So the real question for me is whether gender in France works in such a way that it blocks out what is happening in transnational feminism, in anti-colonial gender studies. It pretends like that does not exist. It breaks those alliances. It doesn't pursue those alliances. In Latin America, gender studies now it is extremely important. And it is all in deep alliance with anti-colonial struggles, and post-colonial struggles. There is no way to do the one without the other. What I fear is that France determines its own debates in a way that is completely cut off from the world. Even the question you pose me is one that is amazing to me. It means I have come to a different culture and I don't know its language. I am a shocked ethnographer at this moment. It is like French universalism. It exists nowhere, except in France [rires]. And yet you call it universal as though it were evident, right? It is shocking. It is like: "Look" - says the anthropologist - "Look at the way those people speak! They call this universalism. It's shocking, it is amazing."

JS: An ethnocentric question - is this what you would call a certain "nombrilisme", an idea that you focus on your own...

JB: It is amazing. But it is interesting too, you know, "je suis là". 